\title{
Long-term effects of destruction of hermatypic corals by Acanthaster planci infestation on reef fish communities at Iriomote Island, Japan
}

\author{
Mitsuhiko Sano, Makoto Shimizu \& Yukio Nose \\ Department of Fisheries, Faculty of Agriculture, University of Tokyo, 1-1-1 Yayoi, Bunkyo-ku, Tokyo 113, Japan
}

\begin{abstract}
Long-term changes in structure of fish communities on coral reefs infested by the coralfeeding starfish Acanthaster planci were determined using $20 \mathrm{~m}^{2}$ visual transects. We censused a living coral reef consisting mainly of staghorn Acropora spp. at Sakiyama Bay and a dead coral reef with low structural complexity of coral branches (about 2 yr after A. planci infestation) at Amitori Bay, Iriomote Island (Ryukyu Islands, Japanj in September 1984. Two yr later, we recensused the dead coral reef, which had changed into a flat plain of unstructured coral rubble ('rubble reef'). Mean numbers of species and individuals per transect severely decreased in the following order of reef types: (1) living reef (1984), (2) dead reef (1984), and (3) rubble reef (1986). Correlated with these decreases in numbers were several patterns: (1) coral-polyp feeders completely disappeared on both dead and rubble reefs, probably due to absence of food; (2) numbers of resident species and individuals decreased on the dead reef, perhaps due to decrease in living space or shelter associated with the reduction in structural complexity of coral branches; and (3) numbers of species and individuals of both resident and visitor fishes declined on the unstructured rubble reef, likely due to shortage of living space and food.
\end{abstract}

\section{INTRODUCTION}

Population outbreaks of the coral-feeding starfish Acanthaster planci have been reported to occur widely on coral reefs at various localities throughout the IndoWest Pacific since the late 1960s (e.g. Endean \& Chesher 1973, Endean \& Cameron 1985, Yamaguchi 1986). Hermatypic corals of many reefs have been killed extensively by the starfish, and the biological and physical environment of infested reefs has changed drastically (e.g. Endean 1973, Nishihira \& Yamazato 1974). After attack by A. planci, the skeletons of corals become coated with tufts of various filamentous algae, and after a few years the exposed skeletons of branching corals collapse due to biological and physical erosion (review by Hutchings 1986).

Some workers have found that fish community structure varies among different reef habitats (e.g. Chave \& Eckert 1974, Goldman \& Talbot 1976, Gladfelter \& Gladfelter 1978, Gladfelter et al. 1980, Williams 1982, Bell \& Galzin 1984). Thus we expected that the structure of fish communities associated with coral reefs damaged by Acanthaster planci would be altered as a result of environmental changes. However, previous studies of the influence of coral destruction by Acanthaster planci infestation on fish communities are restricted to observations shortly after reef degradation (Bouchon-Navaro et al. 1985, Williams 1986) and comparisons of fish communities on living and dead coral colonies (Sano et al. 1984a). The present study was initiated to determine long-term changes in fish communities on large reefs 4 yr after damage by $A$. planci.

\section{METHODS}

This study was carried out in the fringing reefs of Sakiyama and Amitori bays $\left(24^{\circ} 20^{\prime} \mathrm{N}, 123^{\circ} 42^{\prime} \mathrm{E}\right)$ on the western side of Iriomote Island, one of the Ryukyu Islands of Japan (Fig. 1). Both study reefs, at Sakiyama and Amitori bays, were about $300 \mathrm{~m}$ from the shoreline, and water depth was about $2 \mathrm{~m}$ at high tide and about $1 \mathrm{~m}$ at low tide. The Sakiyama Bay reef consisted mostly of living staghorn coral Acropora spp., forming high structural complexity (Fig. 2A), Live coral cover on the reef was more than $80 \%$. At Amitori Bay, on the other hand, hermatypic corals, especially Acropora and Pocillopora spp., were intensely infested 
with Acanthaster planci between 1981 and 1982, and were completely killed by the end of $1982(\mathrm{H}$. Kohno pers. comm.). By September 1984 the dead coral branches were strikingly degraded by biological and physical erosion, especially by wave action, and structural complexity was very low (Fig. 2B). The dead coral skeletons were coated with filamentous and coralline algae and a deposit of silt. This reef in 1984 is referred to hereafter as 'dead coral reef'. Two yr later (September 1986) the structure of dead coral reef had degraded further due to erosion, and a flat plain of lowrelief coral rubble remained (Fig. 2C, D). This reef in 1986 is referred to as 'rubble reef'. Although we were not able to quantify the decreased complexity of the dead and rubble reefs, the striking extent of the decrease in complexity can be represented by photographs (Fig. 2A to D).

Direct fish observations were carried out on the living and dead coral reefs in September 1984 and on the rubble reef in September 1986. The living reef was not censused in 1986, because predation by Acanthaster planci had reduced live coral cover on the reef to less than $50 \%$ of its cover in 1984 . Five transects $20 \mathrm{~m}$ long and $1 \mathrm{~m}$ wide were established on each reef using a scaled nylon rope. This transect width, rather than a greater width, was found to minimize bias in visual

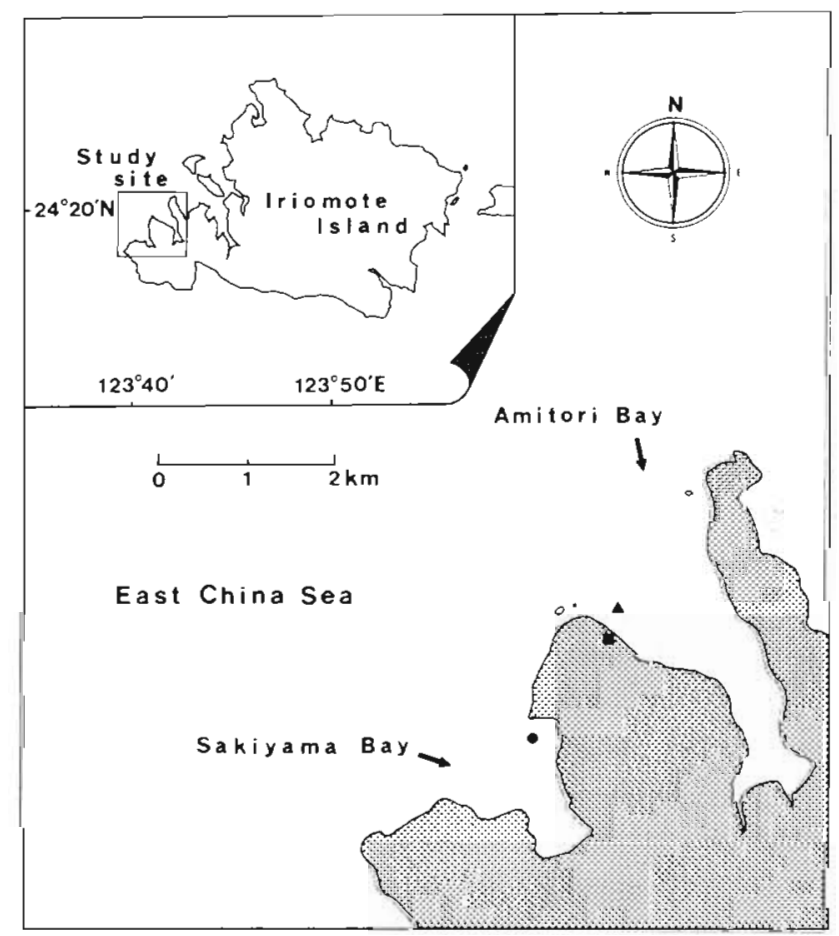

Fig. 1. Map showing study site at Iriomote Island, Ryukyu Islands, Japan. Dotted line indicates reef margin. (•) Living coral reef, 1984; ( $\mathbf{\Lambda}$ ) dead coral reef, 1984 and rubble reef, 1986; (-) Okinawa Regional Research Center, Tokai University transect censuses in methodical tests by Sale \& Sharp (1983). Using a mask and snorkel, a single diver (the first author) slowly approached each transect. 'Visitor' fishes, which swam across the transect but which consistently fled at our approach, were first censused visually for 10 min (Gooding \& Magnuson 1967, Smith \& Tyler 1972). 'Resident' fishes, which stayed permanently on the transect and did not flee at our approach, were then counted by swimming along the transect and carefully inspecting the entire area until all visible residents were recorded. Each transect required approximately 30 to $60 \mathrm{~min}$ to census. Fishes were identified to species, and the number of individuals of each species was recorded on a plastic slate. All censuses were made at high tide between 1000 and $1400 \mathrm{~h}$ and each transect was censused once.

Fish species diversity was calculated using the Shannon-Wiener index (Shannon \& Weaver 1949):

$$
\mathrm{H}^{\prime}=-\sum_{\mathrm{i}=1}^{\mathrm{s}} \mathrm{P}_{\mathrm{l}} \log _{2} \mathrm{P}_{\mathrm{i}}
$$

where $P_{i}=$ proportion of individuals of species $i$ in the sample; $\mathrm{s}=$ number of species.

Based on available published dietary data of coral reef fishes (Hiatt \& Strasburg 1960, Hobson 1974, Allen 1975, 1980, Sano et al. 1984b), fishes censused were assigned to one of 6 trophic categories: herbivores, zooplankton feeders, benthic-animal feeders, omnivores, coral-polyp feeders, and piscivores. Food habits of some fishes not previously examined were tentatively determined by our underwater observations of feeding behavior. The scientific names of all fishes censused follow the nomenclature used by Masuda et al. (1984).

\section{RESULTS}

Species of fishes and density of individuals associated with the transects at each reef are shown in Table 1. Sixty-two species were found on the living reef, while 43 and 22 species were recorded on the dead and rubble reefs, respectively. The mean numbers of species and individuals per transect decreased remarkably in the following order of reef types: (1) living reef (1984), (2) dead reef (1984), and (3) rubble reef (1986) (Table 2). Mean species diversity measured for each reef showed no significant difference between the living and dead reefs (Mann-Whitney U-test, p >0.20) (Table 2). However, the diversity of the rubble reef was significantly lower than diversities of the living and dead reefs $(p<0.05)$.

Since the food resources of fishes (especially coral polyps and filamentous algae) and the structural complexity of coral branches varied with coral death, we 

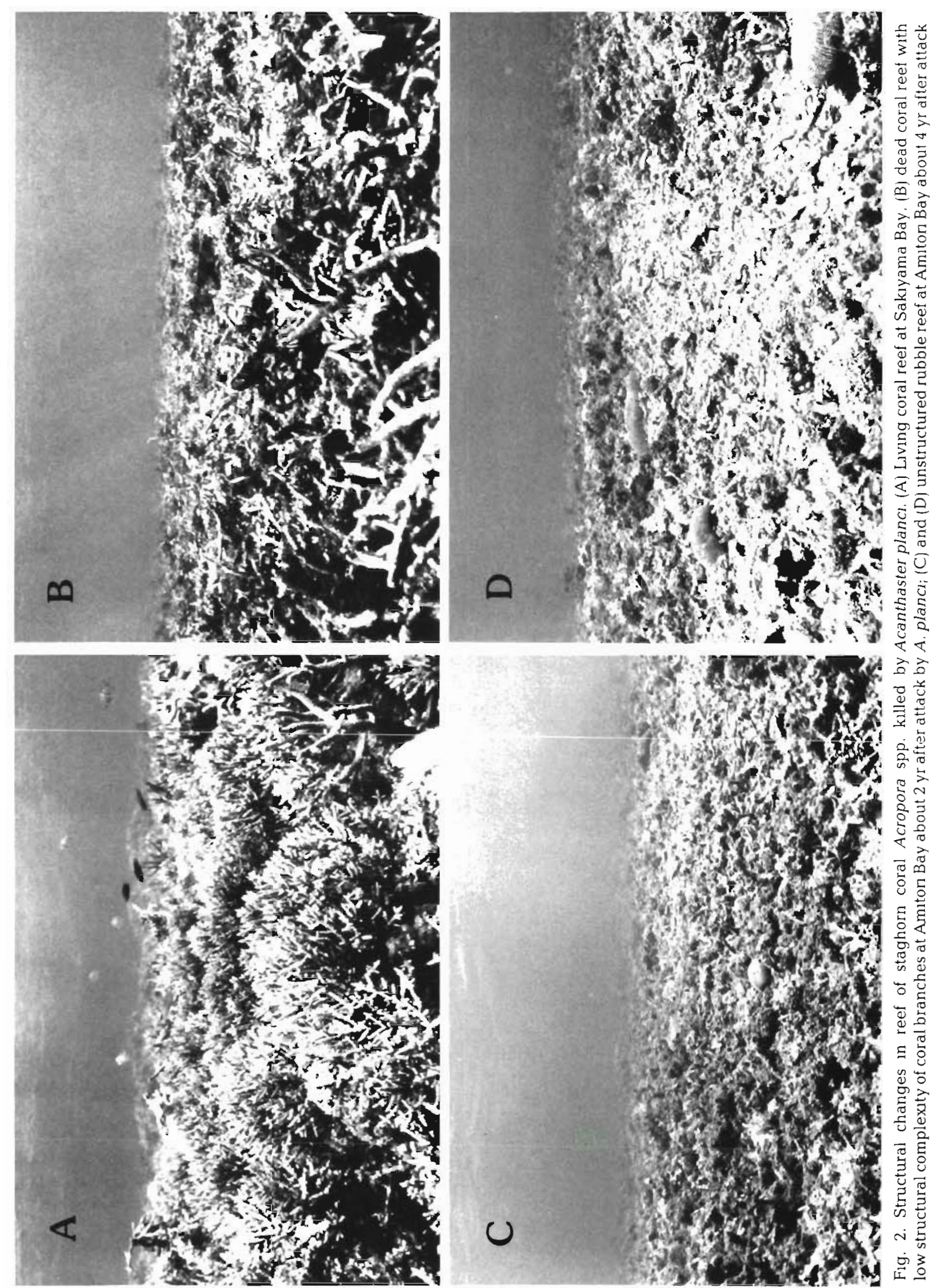

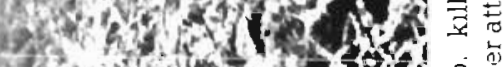

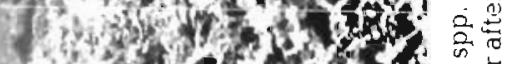

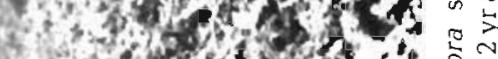

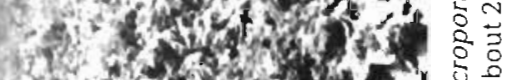

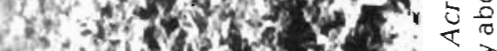

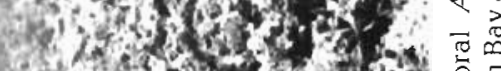

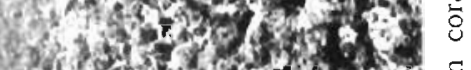
14)

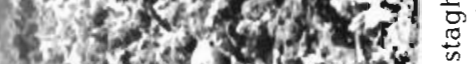

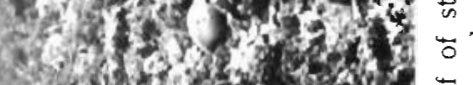

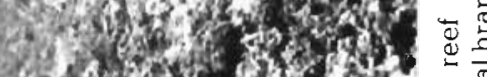

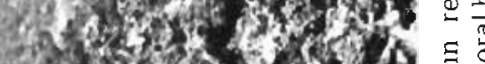

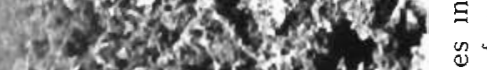

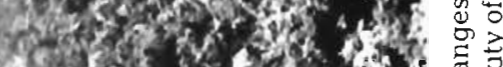

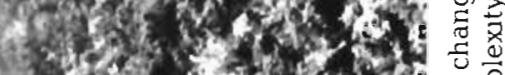
3 is collow

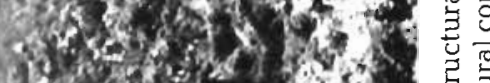

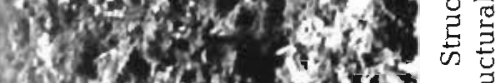

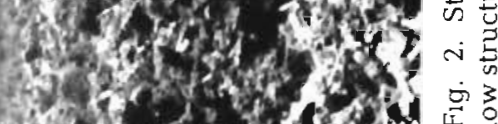


Table 1. Mean number of individuals per transect $\left(20 \mathrm{~m}^{2}\right)$ by species observed on each reef, listed in order of decreasing abundance on the living reef. Year each reef was sampled is included in parentheses. Dead reef and rubble reef were the same reef sampled $2 \mathrm{yr}$ apart. Values are mean $\pm 95 \%$ confidence limits of the mean $(n=5$ transects). Trophic category (TC): $H$, herbivore; O, omnivore; $B$, benthic-animal feeder; $C$, coral-polyp feeder; $Z$, zooplankton feeder; P, piscivore. Residency: R, resident; $\mathrm{V}$, visitor. - : not observed

\begin{tabular}{|c|c|c|c|c|c|c|}
\hline Species & Family & TC & Residency & $\begin{array}{l}\text { Living reef } \\
\quad(1984]\end{array}$ & $\begin{array}{c}\text { Dead reef } \\
(1984)\end{array}$ & $\begin{array}{c}\text { Rubble reef } \\
\text { (1986) }\end{array}$ \\
\hline Pomacentrus moluccensis & Pomacentridae & 0 & $\mathrm{R}$ & $55.4 \pm 6.0$ & $13.8 \pm 10.3$ & $0.2 \pm 0.6$ \\
\hline Atrosalarias fuscus holomelas & Blenniidae & $\mathrm{H}$ & $\mathrm{R}$ & $33.0 \pm 3.4$ & $4.8 \pm 5.7$ & - \\
\hline Chelloprion labiatus & Pomacentridae & C & $\mathrm{R}$ & $29.2 \pm 6.2$ & - & - \\
\hline Gobiodon citrinus & Gobiidae & C & $\mathrm{R}$ & $14.8 \pm 2.7$ & - & - \\
\hline Amblyglyphidodon curacao & Pomacentridae & 0 & $\mathrm{R}$ & $10.8 \pm 11.0$ & - & - \\
\hline Pomacentrus sp. & Pomacentridae & 0 & $\mathrm{R}$ & $9.2 \pm 2.8$ & $9.0 \pm 1.2$ & $0.2 \pm 0.6$ \\
\hline Stegastes nugricans & Pomacentridae & $\mathrm{H}$ & $\mathrm{R}$ & $7.8 \pm 4.1$ & $3.2 \pm 2.7$ & - \\
\hline Chaetodon trifasciatus & Chaetodontidae & C & $\mathrm{v}$ & $7.8 \pm 2.7$ & & - \\
\hline Ctenochaetus striatus & Acanthuridae & $\mathrm{H}$ & $\mathrm{v}$ & $4.4 \pm 2.9$ & $5.6=1.4$ & $1.6 \pm 2.3$ \\
\hline Labrichthys unilineatus & Labridae & C & $\mathrm{v}$ & $3.8 \pm 2.0$ & - & - \\
\hline Epinephelus merra & Serranidae & B & $\mathrm{R}$ & $3.2 \pm 1.6$ & $3.2 \pm 1.0$ & $1.0 \pm 0.9$ \\
\hline Scarus sordidus & Scaridae & $\mathrm{H}$ & $\mathrm{v}$ & $3.0 \pm 1.5$ & $3.6 \pm 1.4$ & $2.4 \pm 2.9$ \\
\hline Oxymonacanthus longirostris & Monacanthidae & C & $\mathrm{v}$ & $2.4 \pm 2.7$ & - & - \\
\hline Chaetodon trifascialis & Chaetodontidae & C & $\mathrm{v}$ & $2.0 \pm 1.2$ & - & - \\
\hline Zebrasoma scopas & Acanthuridae & $\mathrm{H}$ & $\mathrm{v}$ & $2.0 \pm 0.9$ & - & - \\
\hline Gomphosus varius & Labridae & B & $\mathrm{v}$ & $1.8 \pm 1.0$ & $0.4 \pm 0.7$ & $0.2 \pm 0.6$ \\
\hline Siganus vulpinus & Siganidae & $\mathrm{H}$ & $\mathrm{v}$ & $1.8 \pm 1.0$ & $0.8 \pm 1.4$ & - \\
\hline Thalassoma hardwickii & Labridae & B & $\mathrm{V}$ & $1.8 \pm 1.0$ & $2.2 \pm 1.0$ & $1.6 \pm 1.4$ \\
\hline Cheilodipterus quinquelineatus & Apogonidae & B & $\mathrm{R}$ & $1.6 \pm 1.4$ & - & - \\
\hline Paraglyphidodon melas & Pomacentridae & $\mathrm{O}$ & $\mathrm{R}$ & $1.4 \pm 0.7$ & - & - \\
\hline Stegastes lividus & Pomacentridae & $\mathrm{H}$ & $\mathrm{R}$ & $1.4 \pm 0.7$ & - & - \\
\hline Gobiodon okinawae & Gobiidae & C & $\mathrm{R}$ & $1.2 \pm 3.3$ & - & - \\
\hline Chaetodon melannotus & Chaetodontidae & B & $\mathrm{v}$ & $1.2 \pm 1.0$ & $0.4=0.7$ & - \\
\hline Hemigymnus melapterus & Labridae & B & $\mathrm{v}$ & $1.2 \pm 1.0$ & $0.4 \pm 0.7$ & - \\
\hline Zanclus cornutus & Zanclidae & $\mathrm{O}$ & $\mathrm{V}$ & $1.2 \pm 1.0$ & $0.2 \pm 0.6$ & - \\
\hline Epibulus insidiator & Labridae & B & $\mathrm{v}$ & $1.0 \pm 0.9$ & $0.8 \pm 1.0$ & - \\
\hline Dascyllus aruanus & Pomacentridae & 0 & $\mathrm{R}$ & $0.8 \pm 1.4$ & $1.0 \pm 1.8$ & - \\
\hline Meiacanthus atrodorsalis atrodorsalis & Blenniidae & $\mathrm{H}$ & $\mathrm{R}$ & $0.8 \pm 0.6$ & - & - \\
\hline Halichoeres melanurus & Labridae & 0 & $\mathrm{v}$ & $0.8 \pm 1.0$ & $0.2 \pm 0.6$ & - \\
\hline Siganus spinus & Siganidae & $\mathrm{H}$ & $\mathrm{v}$ & $0.8 \pm 2.2$ & $1.0 \pm 2.2$ & - \\
\hline Thalassoma lunare & Labridae & $\mathrm{B}$ & $\mathrm{V}$ & $0.8 \pm 1.0$ & $0.8 \pm 1.0$ & $0.6 \pm 0.7$ \\
\hline Chaetodon kleinii & Chaetodontidae & 0 & $\mathrm{v}$ & $0.6 \pm 1.1$ & $0.2 \pm 0.6$ & $0.2 \pm 0.6$ \\
\hline Centropyge vrolicki & Pomacanthidae & $\mathrm{H}$ & $\mathrm{R}$ & $0.4 \pm 0.7$ & $0.2 \pm 0.6$ & - \\
\hline Chrysiptera cyanea & Pomacentridae & 0 & $\mathrm{R}$ & $0.4 \pm 1.1$ & $0.4 \pm 1.1$ & $0.2 \pm 0.6$ \\
\hline Paracirhites forsteri & Cirrhitidae & B & $\mathrm{R}$ & $0.4 \pm 0.7$ & - & - \\
\hline Cephalopholis urodelus & Serranidae & B & $\mathrm{R}$ & $0.4 \pm 0.7$ & - & - \\
\hline Dampiena cyclophthalma & Pseudochromidae & B & $\mathrm{R}$ & $0.4 \pm 0.7$ & $0.4 \pm 0.7$ & - \\
\hline Chaetodon auriga & Chaetodontidae & B & $\mathrm{v}$ & $0.4 \pm 1.1$ & $0.8 \pm 1.0$ & - \\
\hline Chaetodon lieolatus & Chaetodontidae & $\mathrm{B}$ & $\mathrm{v}$ & $0.4 \pm 0.7$ & - & - \\
\hline Chaetodon unimaculatus & Chaetodontidae & C & $\mathrm{v}$ & $0.4 \pm 0.7$ & - & - \\
\hline Chaetodon vagabundus & Chaetodontidae & 0 & $\mathrm{v}$ & $0.4 \pm 1.1$ & $0.6 \pm 1.1$ & $0.2 \pm 0.6$ \\
\hline Cheilinus diagrammus & Labridae & B & $\mathrm{v}$ & $0.4 \pm 1.1$ & - & - \\
\hline Chromis atripectoralis & Pomacentridae & $\mathrm{O}$ & $\mathrm{V}$ & $0.4 \pm 1.1$ & - & - \\
\hline Heniochus chrysostomus & Chaetodontidae & C & $\mathrm{v}$ & $0.4 \pm 0.7$ & - & - \\
\hline Scarus oviceps & Scaridae & $\mathrm{H}$ & $\mathrm{v}$ & $0.4 \pm 1.1$ & $0.6 \pm 1.1$ & - \\
\hline Scarus dimidiatus & Scaridae & $\mathrm{H}$ & $\mathrm{V}$ & $0.4 \pm 0.7$ & - & - \\
\hline Stethojulis strigiventer & Labridae & Z & $\mathrm{V}$ & $0.4 \pm 1.1$ & $2.0 \pm 0.9$ & $0.2 \pm 0.6$ \\
\hline Corythoich thys haematopterus & Syngnathidae & $\mathrm{z}$ & $\mathrm{R}$ & $0.2 \pm 0.6$ & - & - \\
\hline Dascyllus melanurus & Pomacentridae & $\mathrm{H}$ & $\mathrm{R}$ & $0.2 \pm 0.6$ & - & - \\
\hline Epinephelus caeruleopunctatus & Serranidae & $\mathrm{P}$ & $\mathrm{R}$ & $0.2 \pm 0.6$ & - & - \\
\hline Aulostomus chinensis & Aulostomidae & $\mathrm{P}$ & $\mathrm{v}$ & $0.2 \pm 0.6$ & - & - \\
\hline Chaetodon baronessa & Chaetodontidae & C & $\mathrm{v}$ & $0.2 \pm 0.6$ & - & - \\
\hline Chaetodon bennetti & Chaetodontidae & $\mathrm{C}$ & $\mathrm{V}$ & $0.2 \pm 0.6$ & - & - \\
\hline Chaetodon plebeius & Chaetodontidae & $\mathrm{C}$ & $\mathrm{v}$ & $0.2 \pm 0.6$ & - & - \\
\hline Cheilio inermis & Labridae & $\mathrm{B}$ & $\mathrm{v}$ & $0.2 \pm 0.6$ & $1.0 \pm 1.2$ & $0.4 \pm 0.7$ \\
\hline Cheilimus chlorurus & Labridae & B & $\mathrm{v}$ & $0.2 \pm 0.6$ & $1.0 \pm 0.9$ & $1.0 \pm 0.9$ \\
\hline Hemigymnus fasciatus & Labridae & Z & $\mathrm{v}$ & $0.2 \pm 0.6$ & - & - \\
\hline Naso lituratus & Acanthuridae & $\mathrm{H}$ & $\mathrm{v}$ & $0.2 \pm 0.6$ & $0.2 \pm 0.6$ & - \\
\hline Parupeneus trifasciatus & Mullidae & $B$ & $\mathrm{v}$ & $0.2 \pm 0.6$ & $2.0=0.9$ & $1.2 \pm 1.6$ \\
\hline Siganus puellus & Siganidae & $\mathrm{H}$ & $\mathrm{v}$ & $0.2 \pm 0.6$ & - & - \\
\hline Thalassoma janseni & Labridae & $\mathrm{B}$ & $\mathrm{v}$ & $0.2 \pm 0.6$ & - & - \\
\hline Zebrasoma veliferum & Acanthuridae & $\mathrm{H}$ & $\mathrm{v}$ & $0.2 \pm 0.6$ & - & - \\
\hline Hologymnosus annulatus & Labridae & B & $\mathrm{V}$ & - & $1.0 \pm 1.2$ & $0.2=0.6$ \\
\hline Salarias fasciatus & Blenniidae & $\mathrm{H}$ & $\mathrm{R}$ & - & $0.8 \pm 0.6$ & $0.2 \pm 0.6$ \\
\hline Naso sp. & Acanthuridae & $\mathrm{H}$ & v & - & $0.6 \pm 1.1$ & - \\
\hline Centropyge heraldi & Pomacanthidae & $\mathrm{H}$ & $\mathrm{R}$ & - & $0.4 \pm 0.7$ & - \\
\hline Cheilinus rhodochrous & Labridae & B & $\mathrm{v}$ & - & $0.4 \pm 1.1$ & - \\
\hline Choerodon anchorago & Labridae & B & V & - & $0.4 \pm 0.7$ & $0.4 \pm 1.1$ \\
\hline Scarus frenatus & Scaridae & $\mathrm{H}$ & $\mathrm{V}$ & - & $0.4 \pm 0.7$ & - \\
\hline Stethojulis bandanensis & Labridae & $\mathrm{Z}$ & v & - & $0.4 \pm 0.7$ & - \\
\hline Halichoeres trimaculatus & Labridae & B & $\mathrm{v}$ & - & $0.4 \pm 0.7$ & - \\
\hline Apogon cooki & Apogonidae & $B$ & $\mathrm{R}$ & - & $0.2 \pm 0.6$ & - \\
\hline Meiacanthus kamoharai & Blenniidae & 0 & $\mathrm{R}$ & - & $0.2 \pm 0.6$ & - \\
\hline Chaetodon rafflesi & Chaetodontidae & B & $\mathrm{v}$ & - & $0.2 \pm 0.6$ & - \\
\hline Scarus schlegeli & Scaridae & $\mathrm{H}$ & $\mathrm{v}$ & - & $0.2 \pm 0.6$ & - \\
\hline pomacentrus rhodonotus & Pomacentridae & $O$ & $\mathrm{R}$ & - & - & $3.8 \pm 1.6$ \\
\hline Parapercis cylindrica & Mugiloididae & 0 & $\mathrm{R}$ & - & - & $1.8 \pm 0.6$ \\
\hline Scarus sp. & Scaridae & $\mathrm{H}$ & $\mathrm{v}$ & - & - & $0.6 \pm 1.1$ \\
\hline Paripeneus cyclostomus & Mullidae & B & $\mathrm{v}$ & - & - & $0.2 \pm 0.6$ \\
\hline Total number of species & & & & 62 & 43 & 22 \\
\hline
\end{tabular}


compared fish communities on the 3 reefs by trophic category and by residency (Sano et al. 1984a). The mean numbers of species and of individuals per tran-

Table 2. Mean numbers of species and individuals and species diversity per transect $\left(20 \mathrm{~m}^{2}\right)$ on each reef. Year each reef was sampled is included in parentheses. Dead reef and rubble reef were same reef sampled 2 yr apart. Values are mean $\pm 95 \%$ confidence limits of the mean ( $n=5$ transects)

\begin{tabular}{|c|c|c|c|}
\hline Parameter & $\begin{array}{l}\text { Living reef } \\
\text { (1984) }\end{array}$ & $\begin{array}{c}\text { Dead reef } \\
(1984)\end{array}$ & $\begin{array}{c}\text { Rubble reef } \\
\text { (1986) }\end{array}$ \\
\hline Number of species & $34.6 \pm 2.9$ & $22.6 \pm 2.1$ & $9.8 \pm 2.0$ \\
\hline $\begin{array}{l}\text { Number of } \\
\text { individuals }\end{array}$ & $218.0 \pm 12.0$ & $66.4 \pm 18.2$ & $18.4 \pm 3.0$ \\
\hline Species diversity & $3.80 \pm 0.17$ & $3.92 \pm 0.30$ & $3.03 \pm 0.33$ \\
\hline
\end{tabular}

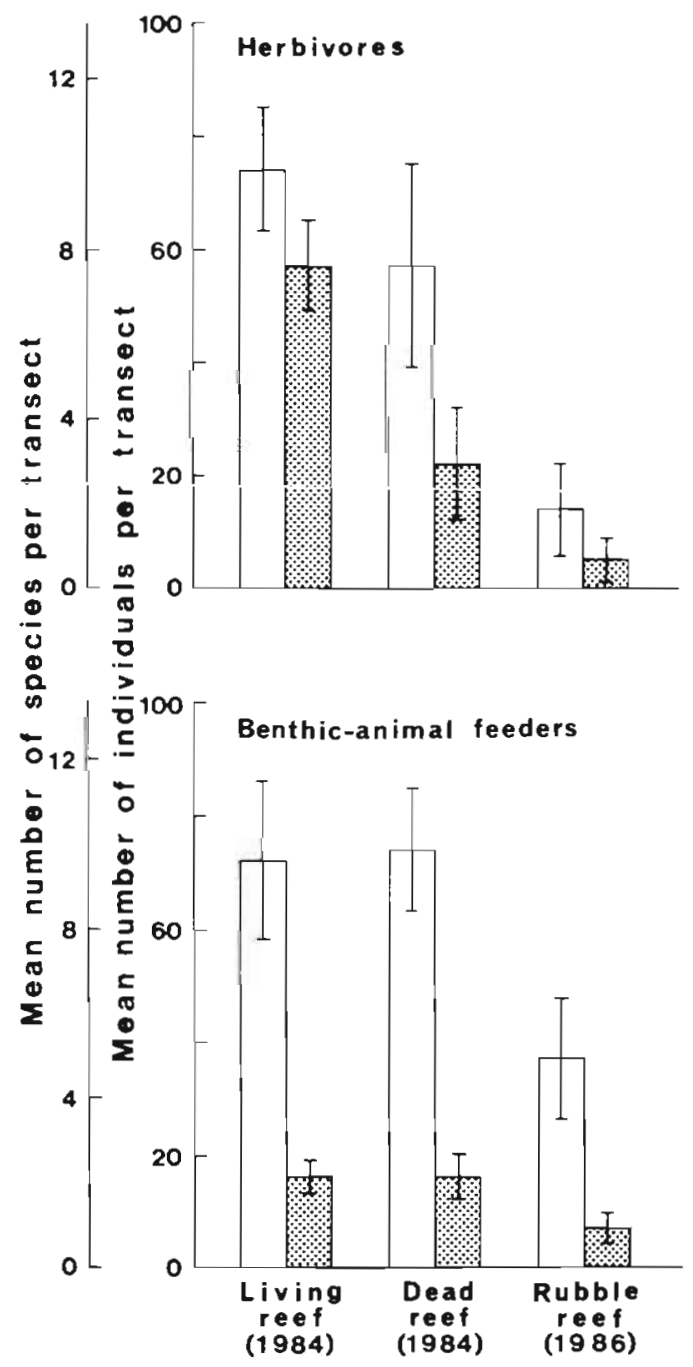

sect in each trophic category on each reef are summarized in Fig. 3. Zooplankton feeders and piscivores were excluded in this analysis, because fish in these categories were rare. Differences among the reefs were most distinct for the coral-polyp feeders: no coral-feeding fish were found on either dead and rubble reefs. Comparisons of the abundances of fishes in other trophic categories among the 3 reefs indicated that the lowest numbers of species and individuals were obtained from the rubble reef for all categories, except for the number of omnivorous species which showed no significant difference between the dead and rubble reefs (U-test, $p>0.20$ ). Herbivores and benthic-animal feeders showed no significant differences in the number of species on the living and the dead reefs (herbivores, $p>0.05$; benthic-animal feeders, $p>0.20$ ). The number of omnivorous species, how-
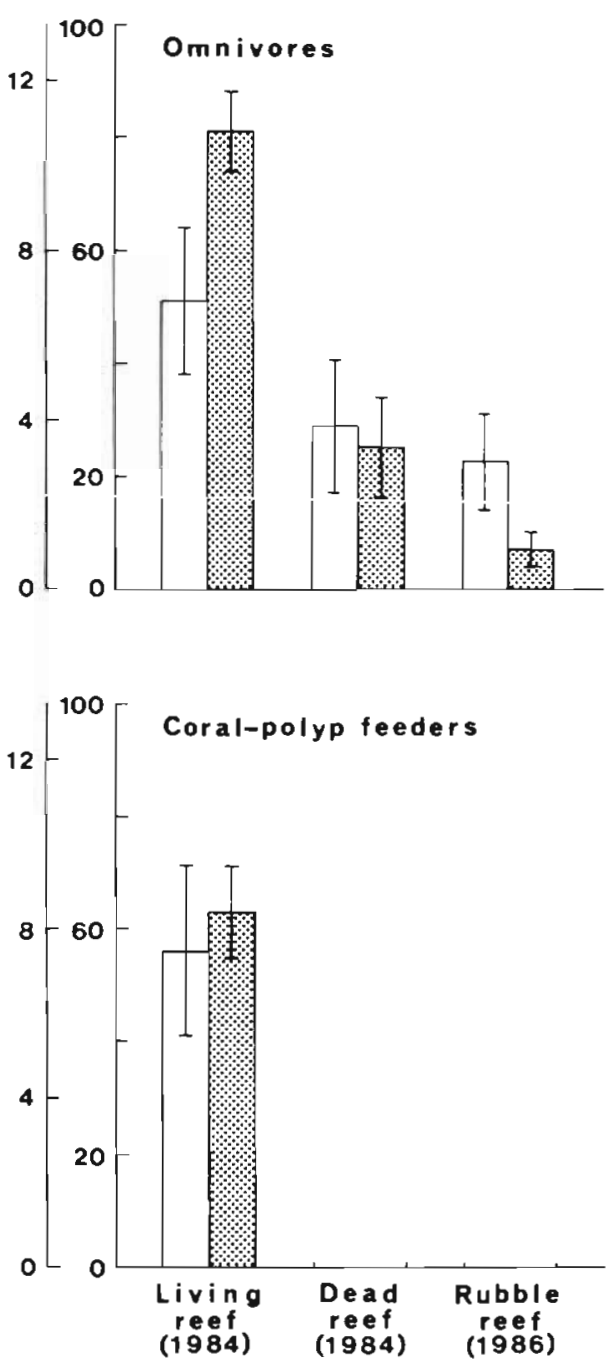

Fig. 3. Mean numbers of species (open bars) and of individuals (stippled bars) per transect for each trophic category on each reef. Vertical lines indicate $95 \%$ confidence limits of the mean ( $n=5$ transects). Year each reef was sampled is included in parentheses 
ever, was significantly greater on the living reef compared with the other reefs $(p<0.05)$. Much greater numbers of herbivorous and omnivorous individuals were counted from the living than the other reefs, but number of individuals of benthic-animal feeders showed no significant difference between the living and dead reefs $(p>0.20)$.

Fig. 4 compares the numbers of resident and visiting species and individuals on the 3 reefs, except for the coral-polyp feeders which were omitted because they were not found on the dead and rubble reefs. In the numbers of resident species and individuals, the following significant differences among the reefs were found: living reef $>$ dead reef $>$ rubble reef (U-test, $p<0.05$ ). The differences in the numbers of visitor species and individuals are as follows: living reef $=$ dead reef $>$ rubble reef, with all differences significant at $\mathrm{p}<0.05$. To provide a more detailed analysis, fishes known to be herbivores, omnivores, and benthic-animal feeders were grouped as either resident or visitor (Fig. 5). For all trophic categories, resident and visitor fishes showed almost the same decreasing trends among the reefs as in Fig. 4, with a few exceptions, such as the number of species of resident omnivores on the rubble reef.

Finally, the mean number of individuals per transect was compared species by species among the 3 kinds of reefs (Table 1). Most of the abundant fishes on the living reef decreased severely in abundance or completely disappeared on the rubble reef. For instance, the resident omnivore Pomacentrus moluccensis, which was the predominant species on the living reef, was markedly less numerous on the dead reef and was represented by a single individual on the rubble reef. Conversely, Parupeneus trifasciatus, a visitor benthicanimal feeder, showed significantly greater number of individuals on the dead than on the living reefs (U-test, $\mathrm{p}<0.05$ ). The 2 resident omnivores, Pomacentrus rhodonotus and Parapercis cylindrica, occurred on the rubble reef with distinctly high abundance. All individuals of the latter 3 species were juveniles.

\section{DISCUSSION}

Our data indicate that the structures of coral reef fish communities are substantially altered by Acanthaster planci-induced coral death and associated changes in habitat structure. Species number and density of fishes on $A$. planci-damaged reefs decrease, and remain low several years after infestation.

Sano et al. (1984a) discussed the probable course of events in the structure of coral reef fish communities when corals are killed by Acanthaster planci, using natural and experimental Acropora colonies at Okinawa Island, Japan. The most negative effect of coral destruction on the fish communities was that coral-polyp feeders, which were relatively abundant on the living reef, completely disappeared from the dead and the rubble reefs. Endean \& Stablum (1973), Reese (1981), Bouchon-Navaro et al. (1985), and Williams (1986) made similar observations.
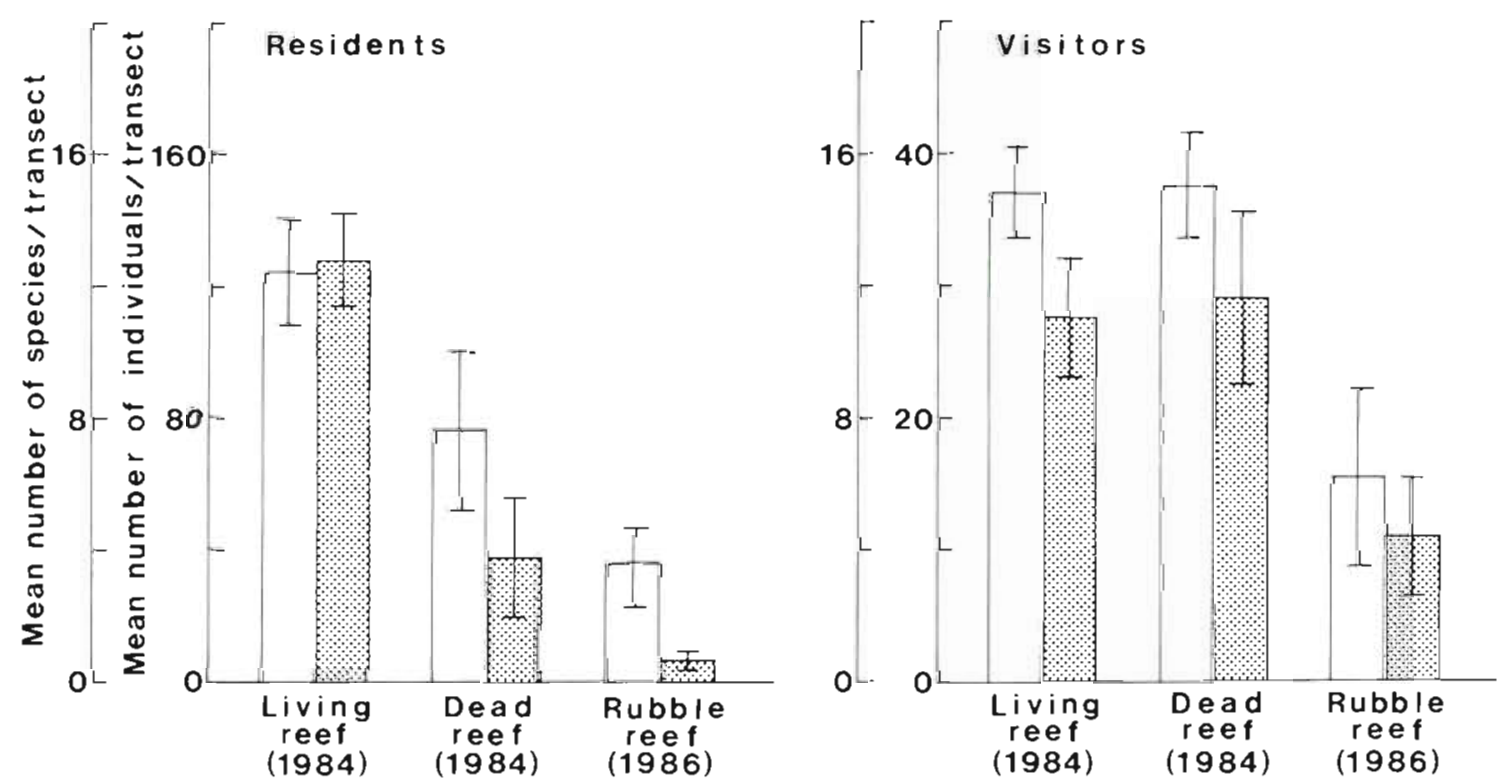

Fig. 4. Mean numbers of species (open bars) and of individuals (stippled bars) per transect for residents and visitors on each reef Vertical lines represent $95 \%$ confidence limits of the mean ( $=5$ transects). Coral-polyp feeders on the living reef were omitted in this analysis (see text). Year each reef was sampled is included in parentheses 

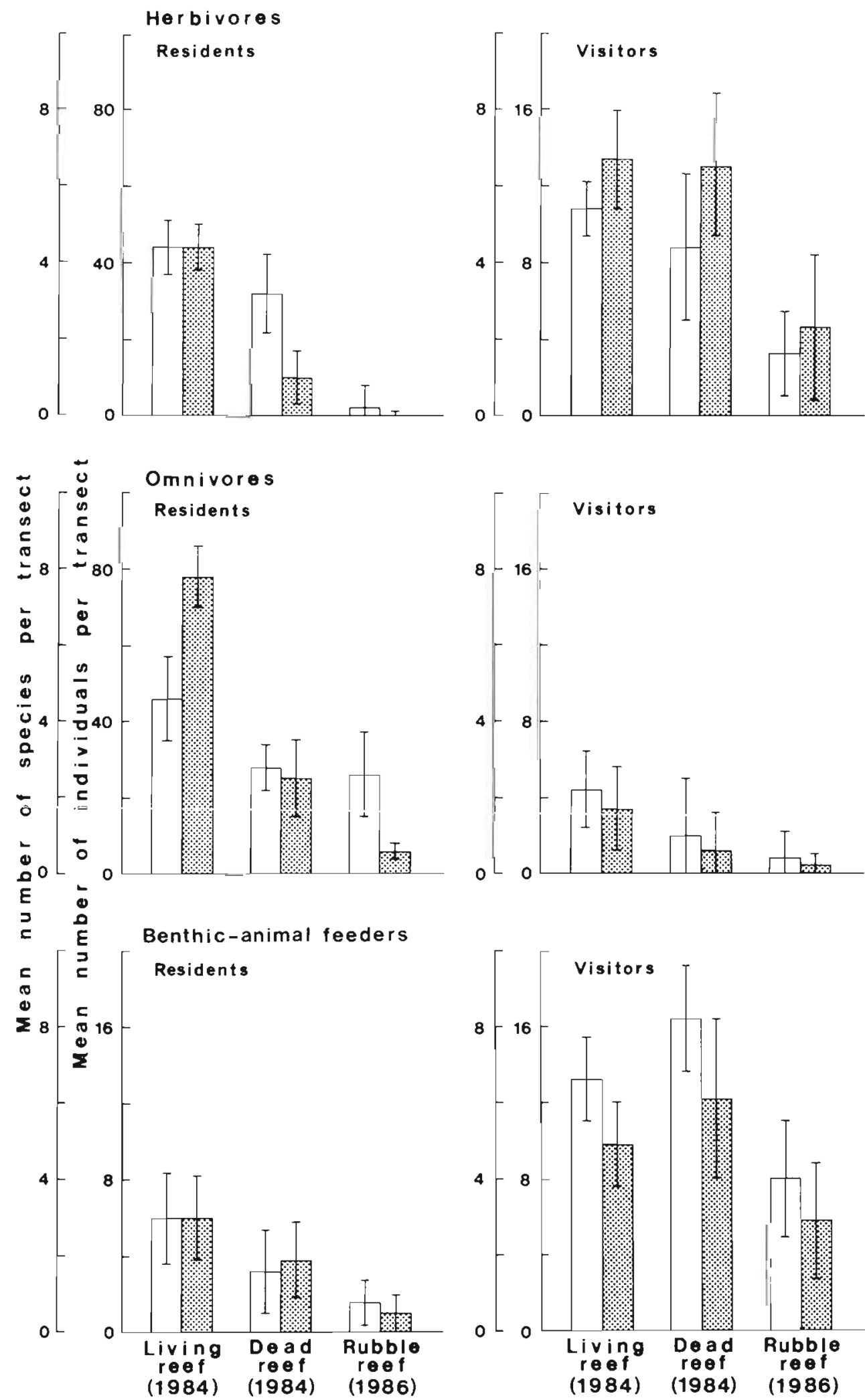

Fig. 5. Mean numbers of species (open bars) and of individuals (stippled bars) per transect for residents and visitors of each trophic category on each reef. Vertical lines indicate $95 \%$ confidence limits of the mean ( $n=5$ transects). Year each reef was sampled is included in parentheses 
The numbers of resident species and individuals markedly decreased on the dead reef with low structural complexity (about 2 yr after Acanthaster planci infestation) and on the unstructured rubble reef (about $4 \mathrm{yr}$ after infestation). The numbers of visitors, on the other hand, showed no significant difference between the living and the dead reefs, but significantly decreased on the rubble reef. The decreases in resident and visitor fish abundance on the unstructured rubble reef may be due to shortage of 2 main resources, living space and food. It seems that visitors as well as residents are negatively affected because of the collapse of their refuge and resting sites when a flat plain of unstructured coral rubble is formed on a large scale. Although we did not examine food resource abundance on the rubble reef, there is evidence indicating decreases in food abundance in such cases. For instance, Alldredge \& King (1977) and Porter et al. (1977) reported that collections from rubble coral contained many fewer demersal zooplankters than those from living coral. Kohn (1967), Kohn \& Leviten (1976), and Sano (1982) have shown that topographically complex reef habitats support more benthic invertebrates such as decapods and gastropods than low-relief reefs. On the other hand, the decreases in resident numbers on the dead reef are probably due to a decrease in only living space or shelter (Sano et al. 1984a). This explanation may be supported by the fact that visitors in each trophic category did not significantly decrease on the dead reef compared with resident species (Fig. 5). If the abundance of available food markedly decreased on the dead reef, visitor species which were not closely dependent on coral for cover should have decreased in numbers also.

Several workers have demonstrated that fish species richness and diversity are positively correlated with topographic complexity of coral reef habitats (Risk 1972, Alevizon \& Brooks 1975, Luckhurst \& Luckhurst 1978, Gladfelter et al. 1980, Carpenter et al. 1981). With only the exception of fish species diversity on the dead coral reef, our results provide further confirmation of these findings.

Walsh (1983) investigated the immediate impact of a catastrophic storm on coral reef fish communities at Kona, Hawaii. The resulting longer-term changes in community structure showed quite different results from our observations. He found no decreases in species and population abundances on quadrats at various habitats after the storm despite considerable storm-induced habitat destruction. We cannot explain this apparent contradiction. Our data suggest that the presence of live coral cover and spatial complexity of the habitat are important factors limiting population abundance of many fishes at Iriomote Island.

We were unable to examine natural variation in species number and abundance of fishes on the reefs at the different locations (i.e. Sakiyama Bay vs Amitori Bay) and times (1984 vs 1986). We cannot confirm that the changes in fish community structure on the dead and the rubble reefs were other than natural variation. Compared with the natural variation in fish community structure indicated by recent studies (e.g. Williams 1986), however, severe changes were observed on the infested reefs. We believe that the observed changes probably resulted from coral destruction by Acanthaster planci.

Acknowledgements. We thank Hiroyuki Yokochi, Akihiro Ishimaru, Hiroyoshi Kohno, Hideo Sunagawa, and the Okinawa Regional Research Center, Tokai University, for assisting in the field observations and sharing valuable information with us, Jack T. Moyer, Charles Birkeland, and anonymous reviewers substantially improved earlier versions of this paper. This study was made possible by a Postdoctoral Fellowship from the Japan Society for the Promotion of Science and by a Grant-in-Aid for Scientific Research from the Japan Ministry of Education, Science and Culture (No. 61760155).

\section{LITERATURE CITED}

Alevizon, W. S., Brooks, M. G. (1975). The comparative structure of two western Atlantic reef-fish assemblages. Bull. mar. Sci. 25: 482-490

Alldredge, A. L., King, J. M. (1977). Distribution, abundance, and substrate preferences of demersal reef zooplankton at Lizard Island Lagoon, Great Barrier Reef. Mar. Biol. 41: $317-333$

Allen, G. R. (1975). Damselfishes of the south seas. T. F. H Publications, Neptune City

Allen, G. R. (1980). Butterfly and angelfishes of the world, Vol 2. Wiley-Interscience, New York

Bell, J. D., Galzin, R. (1984). Influence of live coral cover on coral-reef fish communities. Mar. Ecol. Prog. Ser. 15: $265-274$

Bouchon-Navaro, Y., Bouchon, C., Harmelin-Vivien, M. L. (1985). Impact of coral degradation on a chaetodontid fish assemblage (Moorea, French Polynesia). In: Proc. Fifth Int Coral Reef Congr., Tahiti, Vol. 5. p. 427-432

Carpenter, K. E., Miclat, R. I., Albaladejo, V. D., Corpuz, V. T. (1981). The influence of substrate structure on the local abundance and diversity of Philippine reef fishes. In: Proc. Fourth Int. Coral Reef Symp., Vol. 2. Manila, p. 497-502

Chave, E. H., Eckert, D. B. (1974). Ecological aspects of the distributions of fishes at Fanning Island. Pacif. Sci. 28: $297-317$

Endean, R. (1973). Population explosions of Acanthaster planci and associated destruction of hermatypic corals in the Indo-West Pacific region. In: Jones, O. A., Endean, R. (ed.) Biology and geology of coral reefs, Vol. II, Biology 1 Academic Press, New York, p. 389-438

Endean, R., Cameron, A. M. (1985). Ecocatastrophe on the Great Barrier Reef. In: Proc. Fifth Int. Coral Reef Congr., Tahiti, Vol. 5. p. 309-314

Endean, R., Chesher, R. H. (1973). Temporal and spatial distribution of Acanthaster planci population explosions in the Indo-West Pacific region. Biol. Conserv. 5: 87-95 
Endean, R., Stablum, W. (1973). The apparent extent of recovery of reefs of Australia's Great Barrier Reef devastated by the crown-of-thorns starfish. Atoll Res. Bull. 168: $1-37$

Gladfelter, W. B., Gladfelter, E. H. (1978). Fish community structure as a function of habitat structure on West Indian patch reefs. Rev. Biol. Trop. 26: 65-84

Gladfelter, W. B., Ogden, J. C., Gladfelter, E. H. (1980). Similarity and diversity among coral reef fish communities: a comparison between tropical western Atlantic (Virgin Islands) and tropical central Pacific (Marshall Islands) patch reefs. Ecology 61: 1156-1168

Goldman, B., Talbot, F. H. (1976). Aspects of the ecology of coral reef fishes. In: Jones, O. A., Endean, R. (ed.) Biology and geology of coral reefs, Vol. III, Biology 2. Academic Press, New York, p. 125-154

Gooding, R. M., Magnuson, J. J. (1967). Ecological significance of a drifting object to pelagic fishes. Pacif. Sci. 21: $486-497$

Hiatt, R. W., Strasburg, D. W. (1960). Ecological relationships of the fish fauna on coral reefs of the Marshall Islands. Ecol. Monogr. 30: 65-127

Hobson, E. S. (1974). Feeding relationships of teleostean fishes on coral reefs in Kona, Hawaii. Fish. Bull. U.S. 72: 915-1031

Hutchings, P. A. (1986). Biological destruction of coral reefs. A review. Coral Reefs 4: 239-252

Kohn, A. J. (1967). Environmental complexity and species diversity in the gastropod genus Conus on Indo-West Pacific reef platforms. Am. Nat. 101: 251-259

Kohn, A. J., Leviten, P. J. (1976). Effect of habitat complexity on population density and species richness in tropical intertidal predatory gastropod assemblages. Oecologia 25: $199-210$

Luckhurst, B. E., Luckhurst, K. (1978). Analysis of the influence of substrate variables on coral reef fish communities. Mar. Biol. 49: 317-323

Masuda, H., Amaoka, K., Araga, C., Uyeno, T., Yoshıno, I. (ed.) (1984). The fishes of the Japanese Archipelago. Tokai University Press, Tokyo

Nishihira, M., Yamazato, K. (1974). Human interference with the coral reef community and Acanthaster infestation of
Okinawa. In: Proc. Second Int. Coral Reef Symp., Vol. 1. Brisbane, p. 577-590

Porter, J. W., Porter, K. G., Batac-Catalan, Z. (1977). Quantitative sampling of Indo-Pacific demersal reef plankton. In: Proc. Third Int. Coral Reef Symp., Vol. 1. Miami, p. 105-112

Reese, E. S. (1981). Predation on corals by fishes of the Family Chaetodontidae: implications for conservation and management of coral reef ecosystems. Bull. mar. Sci. 31: 594-604

Risk, M. J. (1972). Fish diversity on a coral reef in the Virgin Islands. Atoll Res. Bull. 153: 1-6

Sale, P. F., Sharp, B. J. (1983). Correction for bias in visual transect censuses of coral reef fishes. Coral Reefs 2: 37-42

Sano, M. (1982). Ecological changes of coral reef animals caused by destruction of hermatypic corals. Ph. D. Dissertation, Univ. of Tokyo, Tokyo (Japanese)

Sano, M., Shimizu, M., Nose, Y. (1984a). Changes in structure of coral reef fish communities by destruction of hermatypic corals: observational and experimental views. Pacif. Sci. 38: 51-79

Sano, M., Shimizu, M., Nose, Y. (1984b). Food habits of teleostean reef fishes in Okinawa Island, southern Japan. Univ. Mus., Univ. Tokyo, Bull. 25: 1-128

Shannon, C. E., Weaver, W. (1949). The mathematical theory of communication. University of Illinois Press, Urbana

Smith, C. L., Tyler, J. C. (1972). Space resource sharing in a coral reef fish community. In: Collette, B. B., Earle, S. A. (ed.) Results of the Tektite program: ecology of coral reef fishes. Nat. Hist. Mus. Los Angeles County Sci. Bull. 14: 125-170

Walsh, W. J. (1983). Stability of a coral reef fish community following a catastrophic storm. Coral Reefs 2: 49-63

Williams, D. McB. (1982). Patterns in the distribution of fish communities across the Central Great Barrier Reef. Coral Reefs 1: $35-43$

Williams, D. McB. (1986). Temporal variation in the structure of reef siope fish communities (cential Grat Barrier Reef): short-term effects of Acanthaster planci infestation. Mar. Ecol. Prog. Ser. 28: 157-164

Yamaguchi, M. (1986). Acanthaster planci infestations of reefs and coral assemblages in Japan: a retrospective analysis of control efforts. Coral Reefs 5: $23-30$ 